\title{
Antimicrobial activity of Polygonium hydropiper leaves against plant and human pathogenic fungal and bacterial strains
}

\author{
Muhammad Waqas ${ }^{1 *}$, Anwar Ali Shad ${ }^{1}$, Humaira Wasila ${ }^{2}$, Ejaz Ahmad \\ $\mathrm{Khan}^{3}$, Omaira Bashir ${ }^{4}$, Mamoon Ur Rashid ${ }^{3}$ and Imran $\mathrm{Ahmad}^{5}$ \\ 1. Department of Agricultural Chemistry, The University of Agriculture, Peshawar-Pakistan \\ 2. Department of Human Nutrition, The University of Agriculture Peshawar-Pakistan \\ 3. Faculty of Agriculture, Gomal University,D.I.Khan-Pakistan \\ 4. Institute of Chemical Sciences, Gomal University, D.I. Khan-Pakistan \\ 5. Department of Horticulture, The University of Agriculture Peshawar-Pakistan \\ *Corresponding author's email: waqasgandapur404@gmail.com \\ Citation \\ Muhammad Waqas, Anwar Ali Shad, Humaira Wasila, Ejaz Ahmad Khan, Omaira Bashir, Mamoon Ur Rashid and \\ Imran Ahmad. Antimicrobial activity of Polygonium hydropiper leaves against plant and human pathogenic fungal \\ and bacterial strains. Pure and Applied Biology. Vol. 5, Issue 4, pp856-861. \\ http://dx.doi.org/10.19045/bspab.2016.50107
}

Received: $16 / 05 / 2016$

Revised: 28/07/2016

Accepted: 08/08/2016

Online First: 15/08/2016

\section{Abstract}

The present study was conducted to investigate the antimicrobial activities of Polygonium hydropiper L. leaves extract against bacteria and fungi using the disc diffusion method. The extract showed significant antibacterial activities against four strains of gram positive bacteria namely Clavibacter, Staphylococcus aureus, Lactococcous lactis and Bacillus clausii species and four strains of gram negative bacteria namely Escherichia coli, Citrobacter, Proteus and Xanthomonas species. The minimum inhibitory concentration (MIC) values against the bacterial culture were ranged from 16 to $64 \mathrm{ug} \mathrm{mL}{ }^{-1}$. The antifungal activities were found against six toxic fungal strains namely Penicillium, Fusarium, Trichoderma, Aspergillus niger, Pythium, and Acremonium. It was concluded that Polygonium hydropiper methanolic leaves extract acted as an antibacterial and antifungal agent and can be used in wide range of pharmaceuticals industries. Such as Quinine was the first natural product to be produced on industrial scale for its use against malaria.

Keywords: Polygonium Hydropiper. L; Methanol Extract; Leaves; Antimicrobial; Minimum Inhibitory Concentration

\section{Introduction}

Polygonium Hydropiper .L. belongs to the family "Polygonaceae" having high medicinal value. Whole Polygonium plant contain large quantity of secondary metabolites and bioactive compound such as 4-Isobutyl-6-methyl-5-oxo-3a,4,5,7a-
tetrahydro-1H-inden-13-oic acid (named viscosumic acid) and quercetin 3-O-(6"feruloyl)-beta-D-galactopyranoside, and the known 3',5-dihydroxy-3,4',5',7tetramethoxyflavone have been isolated from Polygonum viscosum and polygonic acid [1]. The plant also possesses some 
natural compound having insecticidal characteristic. [2]. Whole plant itself or in combination with some other medicinal herbs are used as remedies against various infectious diseases such as diarrhea, itching skin, dyspepsia, excessive menstrual bleeding and hemorrhoid [3]. This species has high pharmacological characteristic and having economical value. Therefore utilization of these herbal plants is increasing day by day among the people. The rate of the pathogenic infectious diseases is increasing day by day worldwide because of exposure to the adverse atmosphere in developing countries and therefore mortality rate is also high in these countries. Thus it is need of the day to make remedies against these pathogenic diseases [4]. In order to get rid from this infectious disease many discoveries have been made by using plants against microbial activities on local level as an alternate of synthetic medicines [5]. The present study was conducted with the aims to investigate the antimicrobial activities of methanol extract of Polygonium hydropiper leaves.

\section{Material and Methods}

\section{Plant material collection}

The leaves of the Polygonium hydropiper (L) were collected from Tehsil Muree, District Rawalpindi, Punjab, Pakistan. The leaves of the plant were identified at Department of Agronomy Faculty of Agriculture Gomal University Dera Ismail Khan.

\section{Plant material extraction}

The leaves were washed with tap water and then were cut with manual cutter and dried at $50{ }^{\circ} \mathrm{C}[6]$. After drying they were ground with help of grinding machine and powdered sample was stored in an air tight container. The powder of the leaves sample $(250 \mathrm{~g})$ was extracted through cold extraction method by using methanol (1 L) in flat bottom flask. When the mixture was completely dissolved, it was filtrated using
Watsmann filter paper and the filtrate was separated from solvent using rotary evaporator to get the crude extract [7].

\section{Organism collection}

Antimicrobial activities and minimum inhibitory concentration were investigated against different strain of bacterial and fungal cultural. The antibacterial and minimum inhibitory concentration was determined against four gram-positive bacteria Clavibacter, Staphylococcus aureus, Lactococcous lactis and Bacillus Clausii and four gram negative bacteria Escherichia coli, Citrobacter, Proteus and Xanthomonas. The antifungal screening was conducted against four strain of the fungus Penicillium, Fusarium oxysporum, Trichoderma, Aspergillus Niger, Pythium, and Acremonium. The entire organisms were collected from the Toxicology Laboratory, Department of Agricultural Chemistry, Faculty of Nutrition Sciences, The University of Agriculture Peshawar, Pakistan.

\section{Media for the growth of fungal and bacterial cultural}

Nutrient Broth media (Difco laboratories) having $\mathrm{pH}$ 6.8, nutrient agar media having pH 7.2 and Potato dextrose agar (PDA) media having $\mathrm{pH} 5.6$ were used for antibacterial minimum inhibitory concentration and antifungal screening.

\section{Antibacterial screening}

Antibacterial activity of the plant extract was tested by agar disc diffusion method [8]. Filter disc $(6 \mathrm{~mm})$ were placed on the petri dishes pre-inoculated with bacterial pathogen. The plant methanol extract were poured onto the filter disc. Dimethyl sulphoxide (DMSO) was used $(10 \mu \mathrm{g} / \mu \mathrm{L})$ as negative control against the tested bacterial strain while the Vibromycin $(30 \mu \mathrm{g} /$ disc $)$ was used as positive control. The experiment was repeated three times. All the Petri plates were held for $20 \mathrm{~min}$ at room temperature for the diffusion of the sample extract and 
then kept into an incubator for 24hours at 37

${ }^{0} \mathrm{C}$ for bacterial growth. The zone of inhibition was calculated after 24hrs [9].

\section{Antifungal screening}

The antifungal screening was performed using disc diffusion method. [10]. The antifungal activity was carried out against four pathogenic strains of the fungi at the concentration of $150 \mu \mathrm{g} / \mathrm{disc}$ and $300 \mu \mathrm{g} / \mathrm{disc}$. Dimehtyl sulphoxide (DMSO) $10 \mathrm{ug} / \mathrm{mL}$ was used as negative control while acrobate $20 \mathrm{ug} / \mathrm{disc}$ was used as positive control against four strains of the fungus. All the petri dishes were held for $20 \mathrm{~min}$ at room temperature till to complete diffusion of the extract into the disc and then incubated at 27 ${ }^{\circ} \mathrm{C}$ for 72 hours for fungal growth. The antifungal effect was determined by zone of inhibition and was measured with the help of ruler.

\section{Minimum inhibitory concentration}

The minimum inhibitory concentration of the plant extract was determined by the method described [11]. In order to calculate the MIC the extract of the sample was diluted with nutrient broth of the concentration $50,25,12.5,6.75,3.12$ and $1.56 \mathrm{mg} / \mathrm{mL}$ prepared from stock solution $(500 \mathrm{mg} / \mathrm{mL})$ in test tubes and the control tubes were also prepared. The tubes were incubated at $37{ }^{\circ} \mathrm{C}$ for 24 hours. The minimum concentration of the leaves extract where no bacterial growth was seen was considered as MIC.

\section{Results and discussion}

\section{Antibacterial screening}

The antibacterial screening of methanol extract were presented in Table 1. The maximum MIC (24.2 $\mathrm{mm}$ ) of plant methanol extract was recorded against Calvibacter while lowest MIC (21.1 mm) was observed against Proteus at $300 \mu \mathrm{g} / \mathrm{disc}$. The concentration $150 \mathrm{ug} /$ disc showed maximum activity $(16.3 \mathrm{~mm})$ against Bacillus clausii while minimum zone of inhibition (12.3 $\mathrm{mm})$ was found against Citrobacter. When compared with standard (Vibromycin) at concentration of $30 \mu \mathrm{g} / \mathrm{disc}$. It was noticed that the standard (Vibromycin) showed maximum zone of inhibition $(4 \mu \mathrm{g} / \mathrm{mL})$ against gram positive bacteria Bacillus clausii and Lactococcus followed by Styphylococcus aureus and Clavibacter $(2 \mu \mathrm{g} / \mathrm{mL})$. Similarly it was also found that Standard (Vibromycin) showed maximum inhibitory zone against gram negative bacteria Citrobacter and Proteus $(8 \mu \mathrm{g} / \mathrm{mL})$ followed by Xanthomonas sp and Escherichia Coli at $4 \mu \mathrm{g} / \mathrm{mL}$. In the present research it was also observed that methanol extract showed good result against positive and negative bacterial strains and confirmed the investigation of the previous findings. The figure one shows the zone of inhibition of antibacterial activities. (Figure 1)[12].

Table 1. Results of antibacterial activity of Polygonium hydropiper (L.) leaves Diameter of zone of inhibition (nm)

\begin{tabular}{|c|c|c|c|c|}
\hline \multirow{2}{*}{ Type } & \multirow{2}{*}{ Species } & $\begin{array}{c}\text { MeOH Extract } \\
\text { Conc. }\end{array}$ & $\begin{array}{l}\text { MeOH Extract } \\
\text { Conc. }\end{array}$ & $\begin{array}{l}\text { Vibromycin } \\
\text { (STD) }\end{array}$ \\
\hline & & $\begin{array}{c}\text { 300ug/disc } \\
(\mathrm{M} \pm \mathrm{SE})\end{array}$ & $\begin{array}{c}\text { 150ug/disc } \\
(\mathrm{M} \pm \mathrm{SE})\end{array}$ & $\begin{array}{c}\text { 30ug/disc } \\
(\mathrm{M} \pm \mathrm{SE})\end{array}$ \\
\hline \multirow{4}{*}{ Gram Positive } & Clavibacter & $24.2 \pm 0.6$ & $14.6 \pm 0.4$ & $34.0 \pm 0.0$ \\
\hline & Staphylococcus aureus & $23.1 \pm 0.7$ & $14.5 \pm 0.3$ & $33.0 \pm 0.4$ \\
\hline & Lactococcus lactis & $22.2 \pm 0.3$ & $14.4 \pm 0.2$ & $33.0 \pm 0.3$ \\
\hline & Bacillius clausii & $16.3 \pm 0.2$ & $16.3 \pm 0.1$ & $33.0 \pm 0.0$ \\
\hline \multirow{4}{*}{ Gram -negative } & Xanthomonas sp. & $24.0 \pm 0.0$ & $13.2 \pm 0.7$ & $34.1 \pm 0.2$ \\
\hline & Citrobacter & $23.1 \pm 0.1$ & $12.3 \pm 0.1$ & $33.2 \pm 0.1$ \\
\hline & Escherichia coli & $23.0 \pm 0.3$ & $13.1 \pm 0.1$ & $33.4 \pm 0.0$ \\
\hline & Proteus & $21.1 \pm 0.4$ & $14.2 \pm 0.0$ & $36.0 \pm 0.1$ \\
\hline
\end{tabular}

The Dimethylsulphooxide was used negative control having no zone of inhibition. All the data are as mean of three test \pm SE of the standard grou 


\section{Antifungal screening}

The antifungal screening of the methanolic extract of Polygonium hydropiper L leaves were investigated and results are presented in Table 2. Two different concentrations $150 \mu \mathrm{g} / \mathrm{disc}$ and $300 \mu \mathrm{g} / \mathrm{disc}$ were tested against six fungal strains i.e. Penicillium, Fusarium oxysporum, Trichoderma, Aspergillus niger, Pythium, and Acremonium. The highest activity (18.8 $\mathrm{mm})$ was observed against Fusarium oxysporum followed by Pythium $(18.3 \mathrm{~mm})$ and Penicillium while the minimum zone of inhibition (15.2 \pm 0.4$)$ was showed by Acremonium at $300 \mathrm{ug} / \mathrm{disc}$. The antifungal activity was decreased by decreasing the amount of concentration for all the six

Table 2. Results of antifungal activity of Polygonium hydropiper leaves Diameter of zone of inhibition (nm)

\begin{tabular}{|c|c|c|c|}
\hline \multirow{2}{*}{ Tested fungal sp } & MeOH Extract Conc & $\begin{array}{c}\text { MeOH Extract } \\
\text { Conc. }\end{array}$ & Acrobate (STD) \\
\cline { 2 - 4 } & $\begin{array}{c}300 \mu \mathrm{g} / \mathrm{disc} \\
(\mathrm{M} \pm \mathrm{SE})\end{array}$ & $\begin{array}{c}150 \mu \mathrm{g} / \mathrm{disc} \\
(\mathrm{M} \pm \mathrm{SE})\end{array}$ & $\begin{array}{c}20 \mu \mathrm{g} / \mathrm{disc} \\
(\mathrm{M} \pm \mathrm{SE})\end{array}$ \\
\hline Penicillium & $18.0 \pm 0.0$ & $12.1 \pm 0.3$ & $24.0 \pm 01$ \\
\hline Fusarium oxysporum & $18.8 \pm 0.0$ & $12.0 \pm 0.5$ & $24.3 \pm 04$ \\
\hline Trichoderma & $18.3 \pm 0.2$ & $11.6 \pm 0.6$ & $23.4 \pm 03$ \\
\hline Aspergillus niger & $17.0 \pm 0.3$ & $13.3 \pm 0.0$ & $24.1 \pm 05$ \\
\hline Pythium & $18.5 \pm 0.7$ & $11.0 \pm 0.3$ & $22.4 \pm 07$ \\
\hline Acremonium & $15.2 \pm 0.4$ & $12.7 \pm 0.3$ & $23.1 \pm 0.0$ \\
\hline
\end{tabular}

The Dimethylsulphooxide was used Positive control having no zone of inhibition. All the data are represented as mean of three test \pm SE of the standard group

\section{Minimum Inhibitory Concentration Calculation}

Data in Table 3 represent the Minimum Inhibitory Concentration (MIC) value of the sample plant extract against selected strains of bacteria which were $16,32,16,16,32,32$ and $64 \mu \mathrm{g} / \mathrm{ml}$ against bacterial culture. The minimum inhibitory concentration against four gram positive tested bacterial strains were ranged from $16 \mu \mathrm{g} / \mathrm{ml}$ to $32 \mu \mathrm{g} / \mathrm{ml}$ and fungal species. It was observed that the extract showed maximum activity $(13.3 \pm 0.0)$ against Aspergillus niger while it showed minimum activity (11.0 0.3$)$ against Pythium at $150 \mu \mathrm{g} / \mathrm{disc}$. The standard Vibromycin $(20 \mu \mathrm{g} / \mathrm{disc})$ significantly inhibited the growth of all the six different fungi. Previously literature showed that activities of the various extract have been carried out against various strains of pathogenic fungus [13]. Overall result showed that leaves extract of Polygonium hydropiper has significant effect against tested fungal strains. The figure one shows the zone of inhibition of antifungal activities.(Fig.2). 
Table 3. Minimum Inhibitory Concentration (MIC) of methanolic extract of Polygonium hydropiper

\begin{tabular}{|c|c|c|c|}
\hline \multirow{2}{*}{ Type } & Species & $\begin{array}{c}\text { (MIC) value of( MeOH) } \\
\mathbf{\mu g} / \mathbf{m L}\end{array}$ & $\begin{array}{c}\text { (MIC)value of } \\
\text { Vibromycin } \boldsymbol{\mu g} / \mathbf{m L}\end{array}$ \\
\hline \multirow{3}{*}{ Gram } & Clavibacter & 16 & 2 \\
\cline { 2 - 4 } Positive & Staphylococcus aureus & 32 & 2 \\
\cline { 2 - 4 } & Lactococcus & 16 & 4 \\
\cline { 2 - 4 } & Bacillus Clausii & 16 & 4 \\
\hline \multirow{3}{*}{ Gram } & Xanthomonas & 16 & 8 \\
\cline { 2 - 4 } Negative & Citrobacter & 32 & 4 \\
\cline { 2 - 4 } & Escherichia coli & 32 & 8 \\
\cline { 2 - 4 } & Proteus & 64 & \\
\hline
\end{tabular}
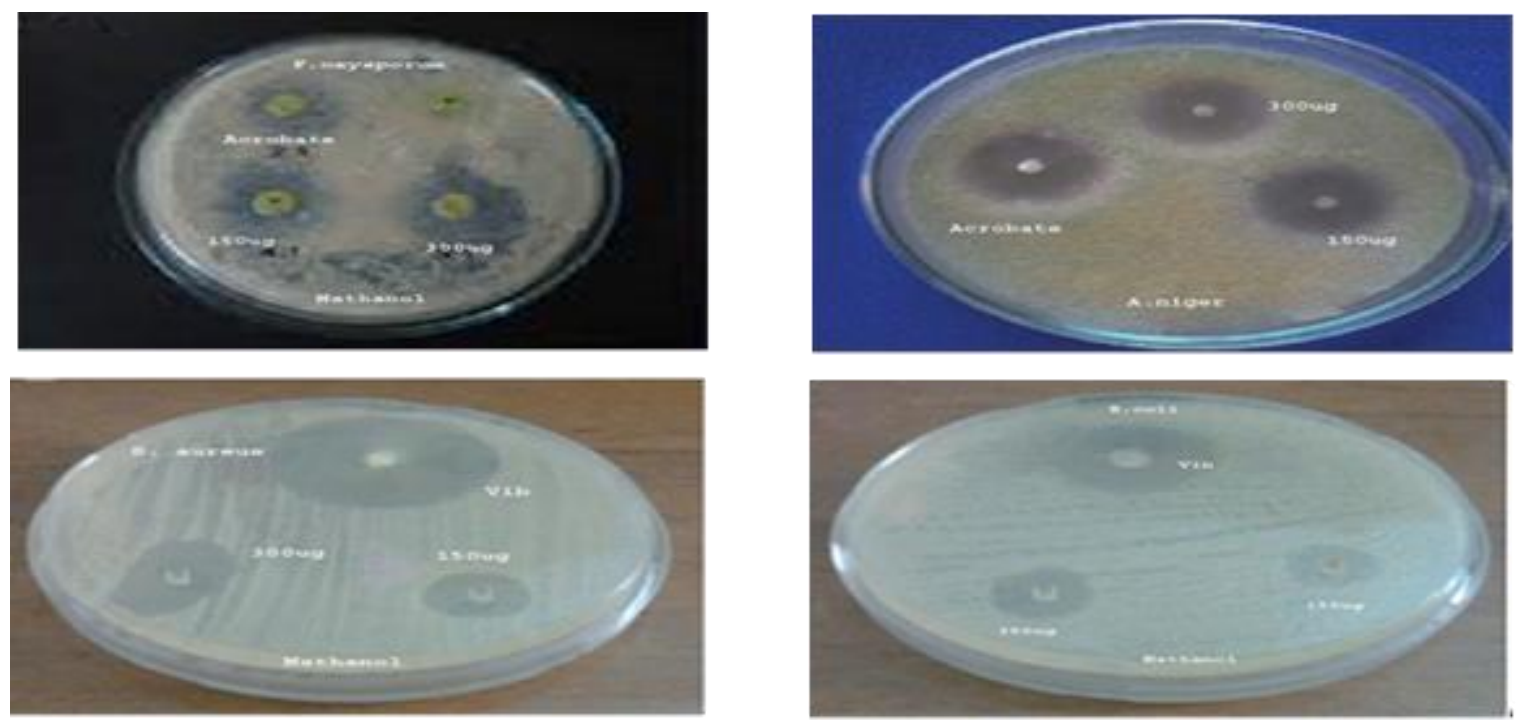

Figure 1. Antimicrobial activities of $\mathrm{MeOH}$ extract at two different concentrations

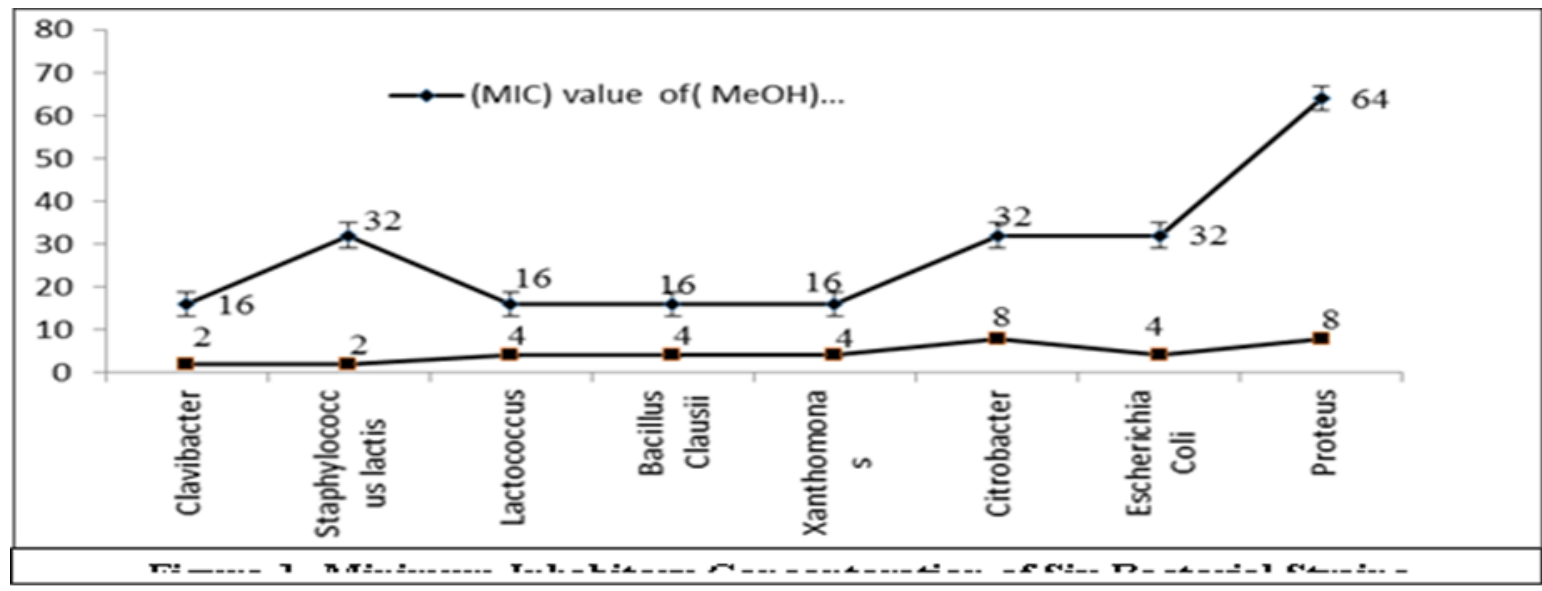

Figure 2. Minimum inhibitory concentration of $\mathrm{MeOH}$ extract against bacterial isolates 


\section{Conclusion and recommendation}

It is concluded from the present research that methanol extract of leaves of Polygonium hydropiper has showed significant antibacterial potential against both gram positive and gram negative bacteria. Moreover the results also showed that extract has strong antifungal activity. Further work is needed to isolate and purify compounds using HPLC. These bioactive compounds can be used against bacterial and fungal strains in most proper way in Pharmaceutical industry.

\section{Authors' contributions}

Conceived and designed the experiments: AA Shad \& M Waqas, Performed the experiments: M Waqas, Analyzed the data: MU Rashid, Provided reagents: O Bashir, Wrote the paper: M Waqas.

\section{Acknowledgement}

The authors are thankful to Prof. Dr. Ejaz Ahmad Khan, Senior Botanist, Chairman, Department of Agronomy Faculty of Agriculture Gomal University Dera Ismail Khan for his kind suggestion and help during research.

\section{References}

1. Furukawa T, Eshima A, Kouya M, Takio S, Takano H \& One K (2002). Coordinate expression of genes involved in catchin biosynthesis in Polygonum hydropiper cells. Plant Cell Reports 21: 385-389.

2. Mollah JU \& Islam W (2005). Effect of Polygonum hydropiper L. extracts on the oviposition and egg viability of Callosobruclues cinensis F. (Coleoptera: Bruchidae). J Biosci 12: 101-109.

3. Chevallier A (1996). The Encyclopedia of Medicinal Plants. Dorling Kindersley. London, ISBN 9-780751-303148, pp: 185.

4. Al-Bari MAA, Sayeed MA, \& Rahman MS (2006). Characterization and antimicrobial activities of a phenolic acid derivative produced by Streptomyces bangladeshiensis, a novel species collected in Bangladesh. Res J Med and Med Sci 1: 77-81.
5. Akinpelu DA \& Onakoyo T (2006). Antimicrobial activities of medicinal plants used in folklore remedies in Southwestern. Afr J Biotech 5(11): 1078-1081.

6. Antara \& Batra (2012). Evaluation of Antimicrobial Activity of different Solvent Extract of Medicinal Plant: Mella Azedarach L. Int J Curr Pharm Res 4, 2, 67-73.

7. Wei W, Xue-Ke Z, Nan W, Yu-jie F \& Yuan gang $Z$ (2006). Antimicrobial activities of essential oil from Artemisiae argyi leaves. $J$ Forestry Res 17(4): 332-334.

8. Khan A, Rahman M \& Islam S (2007). Antibacterial, antifungal and cytotoxic activities of Tuberous Roots of Amorphophallus campanulatus. Turk J Biol 31: 167-172.

9. Dash S, Nath LK \& Bhise S (2005). Antioxidant and antimicrobial activities of Heracleum nepalense D. Don root. Trop J Pharm Res 4: 341-347.

10. Khan A, Rahman M \& Islam S (2007). Antibacterial, antifungal and cytotoxic activities of Tuberous Roots of Amorphophallus campanulatus. Turk J Biol 31: 167-172.

11. Carson, C., F, K., Hammer, A., and Riley, T.V., (1995). Broth micro-dilution method for determination of susceptibility of Escherichia coli and Staphylococcus aureus to the essential oil of Malaleuca alterifolia (Tea tree oil). Microbios 82: 181-185.

12. Jain S, Singh CR \& R Jain (2008). Antimicrobial and antioxidant potentials of Verbesina encelioides (Cav.) Benth and Hook. Fil. Ex. Gray. Res J Med Plant 2(2): 61-65.

13. Asghari G, Nourallahi H, Havaieans SA, Issa L (2006). Antimicrobial activity of Otostegia persica Boiss. Extracts Res Pharm Sci 1: 53-58.

14. Akinyemi K, Oluwa OK \& Omomigbehin EO (2006). Antimicrobial Activity Of Crude Extracts Of Three Medicinal Plants Used In South-West Nigerian Folk Medicine On Some Food Borne Bacterial Pathogens. Afr J Trad 3(4): 13-22. 